\title{
KUALITAS PERSONAL DALAM MENCAPAI ESTETIKA “NGRONCONGI”
}

\author{
Bayu Raditya Prabowo \\ Institut Seni Indonesia Surakarta. \\ Jl. Ki Hajar Dewantara No. 19, Kentingan, Jebres, Surakarta 57126 \\ Email : bayustrato@gmail.com \\ Zulkarnain Mistortoify \\ Institut Seni Indonesia Surakarta.
}

\begin{abstract}
ABSTRAK
Kualitas personal merupakan salah satu komponen pembentuk karakteristik kualitas dalam musik keroncong. Kualitas personal tersebut terbentuk oleh beberapa aspek yang telah meng-embody dalam diri seniman keroncong. Tulisan ini bertujuan untuk mengungkap aspek-aspek beserta operasionalnya dalam membentuk kualitas personal di musik keroncong. Metode penelitian yang digunakan adalah metode kualitatif. Proyeksi tulisan ini akan membahas karakteristik kualitas musik keroncong, dan menggunakan kerangka konseptual yang berasal dari istilah-istilah lokal yang sering digunakan seniman keroncong saat menyajikan pagelaran dalam lingkup musik keroncong. Sebelum mengungkap karakteristik kualitas dalam musik keroncong, penulis akan fokus mengkaji mengenai kualitas personal yang merupakan komponen pembentuk karakteristik kualitas dalam musik keroncong. Kesimpulan penelitian ini adalah kualitas personal dalam musik keroncong terbentuk oleh beberapa aspek yang saling bersinergi, diantaranya akumulasi pengetahuan; kompetensi (skill); interpretasi terhadap lagu keroncong; dan pembawaan secara personal. Beberapa aspek tersebut telah meng-embody dalam diri setiap personal untuk membangun kesadaran secara musikal bahwa musik keroncong menjadi harmonis bukan karena menampilkan virtuositas dari kualitas yang dimiliki oleh setiap personal, melainkan keharmonisan yang tumbuh dari kesadaran ensembleship interpersonal.
\end{abstract}

Kata Kunci: Kualitas, Kualitas Personal, Musik Keroncong.

Personal quality is a component framer of characteristic and quality in keroncong music. The quality of personal was formed by many aspec, who has embodied in artist of keroncong. This paper aimed to explore the aspec of personal quality include the operational to form personal quality in keroncong music. The method of research is qualitatif and use the framework of local conceptual terminology in scope keroncong music often used by artist keroncong in presenting keroncong music. Before uncover characteristic quality, the writer will focus study on the quality of personal in keroncong music. The conclusion in this research is personal quality formed by many aspec with good sinergy. They are knowledge, competency (skill), interpretation to song keroncong, and personal character. Some aspec was embodied in every personal to raise musical awareness that keroncong music be harmonious not for showing virtuosity personal, but harmoniously when high awareness of interpersonal ensembleship

Keyword: The Quality, The Quality of Personal, Keroncong Music

\section{A. Pendahuluan}

Musik keroncong sampai saat ini memiliki daya tarik tersendiri bagi para apresiatornya.. Apresiasi masyarakat terhadap musik keroncong cukup baik, dengan difasilitasi oleh beberapa panggung pertunjukkan maupun media penyiaran yang secara khusus menyajikan musik keroncong, baik berupa festival, siaran radio rutin seminggu sekali, maupun dihadirkan dalam acara-acara tertentu. Kelompok musik keroncong saat ini dapat dikatakan mengalami perkembangan yang sangat pesat, dilihat dari eksistensi kelompok musik keroncong yang telah mempunyai kredibilitas untuk tetap mempertahankan keberadaan musik keroncong, maupun banyaknya kelompok baru yang terbentuk untuk turut melestarikan musik keroncong. Kompetisi musik keroncong juga dewasa ini banyak digelar sebagai ajang untuk berlomba-lomba menyajikan musik keroncong yang berkualitas. 
Apresiasi masyarakat mengenai musik keroncong yang mereka nikmati mengalami respon yang beragam. Beragam respon tersebut berasal dari para penghayat musik keroncong, baik dari sudut pandang penikmat musik keroncong, yang bukan berlatar belakang seniman keroncong, maupun seniman keroncong yang juga sebagai pelaku. Saat musik keroncong tersebut disajikan, muncul beberapa anggapan yang merujuk kepada persoalan kualitas musikalnya. Penikmat musik keroncong, yang tidak memiliki latar belakang seniman keroncong mempunyai sudut pandang tersendiri ketika menilai kualitas musikalnya. Kasus yang terjadi pada realitas adalah, penikmat musik mempunyai anggapan bahwa sajian musik keroncong yang diterima oleh telinga mereka ada yang dirasa "ngroncongi" ada pula yang dianggap tidak memenuhi rasa "ngroncongi". Penilaian yang dilakukan oleh para penikmat musik keroncong tersebut dilihat dari instrumen yang digunakan beserta perannya, dan juga pola dasar musik keroncong yang telah melekat menjadi struktur musik keroncong. Pernyataan mengenai "ngroncongi" atau tidak memenuhi "ngroncongi" bagi para penikmat musik keroncong didasarkan pada hasil refleksi dari kebiasaan mendengarkan musik keroncong.

Seniman keroncong ketika mengapresiasi musik keroncong mempunyai penilaian yang berbeda ketika menyikapi sajian musik keroncong. Musik keroncong yang mereka apresiasi dapat mereka lihat kualitas musikalnya tidak hanya merujuk pada instrument apa yang digunakan, dan juga pola dasar yang digunakan dalam musik keroncong, melainkan mempunyai tingkat kedalaman rasa yang tidak disinggung atau dirasakan oleh penikmat musik keroncong yang tidak berlatar belakangkan seniman keroncong. Apabila penikmat menilai musik keroncong masih pada tingkat pola dasar permaianan musik keroncong, seniman keroncong mempunyai kedalaman lebih, yakni sudah pada ranah interpretasi terhadap lagu keroncong, yang tetap akan dikorelasikan dengan normanorma yang sampai saat ini masih dipatuhi dalam musik keroncong agar dapat mencapai kualitas musikal yang "ngroncongi"

Musik keroncong mempunyai suatu dasar pencapaian kualitas musikal yang sering diungkapkan oleh seniman keroncong dengan istilah "ngroncongi". "'Ngroncongi" merupakan istilah yang mengacu pada bahasa Jawa. Keroncong menjadi kata dasar, yang selanjutnya pada awal kata terda- pat imbuhan "Ng-" dan di akhir kata mendapat imbuhan -i. Sehingga awalnya keroncong merupakan kata benda, beralih menjadi kata sifat setelah berubah menjadi "ngroncongi". "Ngroncongi" adalah suatu garap musik dengan ansambel tertentu yang dilihat dari komposisi musiknya mencirikan musik keroncong. "Ngroncongi" tersebut akan tercapai apabila sesuai dengan estetika dan kultur musik keroncong. "Ngroncongi" juga merupakan dasar pencapaian kualitas musikal yang hanya dimiliki dalam budaya musik keroncong.

Beberapa gejala musikal yang muncul dalam membentuk dasar pencapaian kualitas musik yang "ngroncongi" diantaranya rempek; lelewa; nggali; nyendaren; mbanyumili, nyacah, imbal, langsam, summonspell; nggandul, isen-isen. Gejala musikal yang merupakan dasar pencapaian kualitas musikal yang "ngroncongi" itu lebih sering diungkapkan oleh seniman keroncong yang eksis melestarikan musik keroncong di Surakarta. Penulis dalam hal ini tidak hanya membatasi ruang lingkup penelitian di kota Surakarta saja, namun peneliti juga akan melakukan penelitian ke daerah Tugu, Jakarta yang konon juga menjadi wilayah persebaran keroncong. Alasan menggunakan ruang lingkup Surakarta dan Tugu karena meskipun istilah "ngroncongi" lahir dari seniman keroncong Surakarta, namun esensi karakter kualitas musik keroncong yang memenuhi rasa "ngroncongi" diduga tidak hanya terdapat pada keroncong yang berkembang di Surakarta saja, melainkan komposisi musik keroncong dengan gaya Tugu juga memenuhi rasa yang "ngroncongi".

Pandangan mengenai musik keroncong tersebut dirasa memenuhi kualitas musikal yang "ngroncongi" atau tidak sampai saat ini masih menjadi debatable yang tidak ada habisnya, karena gejala-gejala musikal yang disadari oleh seniman keroncong belum dikomprehensifkan. Ada sebuah keprihatinan yang mendasar terhadap pemahaman masyarakat yang cenderung semakin menipis mengenai musik keroncong, khususnya hal-hal esensial dari sifat atau karakteristik musik keroncong. Perkembangan musik keroncong saat ini oleh beberapa kalangan pecinta musik keroncong sering dinilai telah kehilangan arah (kebablasan) alias tidak "ngroncongi" lagi, berdasarkan asumsi ini penulis memandang perlu untuk mengetahui lebih mendalam tentang hal-hal esensial dari karakteristik musik keroncong. Penulis dalam konteks tulisan ini ingin mengkaji aspek-aspek yang mendasari bagaimana suatu ansambel keroncong tersebut 
mencapai tataran karakteristik kualitas yang baik dalam sajian musik keroncong.

Salah satu aspek yang menjadi dasar pembentukan karakteristik kualitas suatu ansambel musik keroncong yang dirasa "ngroncongi" adalah kualitas personal, karena sebelum adanya relasi interpersonal dalam musik keroncong, perlu adanya pemahaman yang bersifat esensial terkait apa saja yang harus dimiliki seorang seniman keroncong ketika akan memainkan musik keroncong. Persoalan mendasar yang akan diungkap meliputi apa aspek secara mendasar yang harus dimiliki setiap personal seniman keroncong ketika membawakan musik keroncong, dan bagaimana korelasi antar aspek tersebut. Hal ini menjadi menarik untuk dikaji terkait dengan dasar-dasar yang harus dimiliki oleh setiap personal seniman keroncong untuk mencapai karakteristik kualitas estetis dalam musik keroncong. Tujuan tulisan ini adalah untuk membedah hal-hal yang bersifat esensial yang sifatnya telah meng-embody dalam diri seorang seniman keroncong sebagai prinsip dasar pengaplikasian musik keroncong.

Metode penelitian yang digunakan oleh penulis untuk memperoleh informasi mengenai kualitas personal dalam musik keroncong adalah metode kualitatif. Proyeksi tulisan ini nantinya akan membahas karakteristik kualitas musik keroncong, dan menggunakan kerangka konseptual yang berasal dari istilah-istilah lokal dalam ruang lingkup musik keroncong yang sering dipergunakan oleh seniman keroncong dalam menyajikan musik keroncong. Munculnya ungkapan dan juga penganalogian yang dilakukan oleh seniman keroncong, berdasarkan pengetahuan secara personal, dan juga pengetahuan yang telah menjadi umum dalam masyarakat. Sebelum mengungkap karakteristik kualitas dalam musik keroncong, penulis akan fokus mengkaji mengenai kualitas personal dalam musik keroncong, yang juga merupakan komponen pembentuk karakteristik kualitas dalam musik keroncong. Penulis juga menggunakan metode fenomenologi. Pertimbangan penulis dalam menggunakan metode fenomenologi untuk membedah kualitas personal dalam musik keroncong adalah karakteristik kualitas personal dalam musik keroncong ini tidak hanya dimiliki oleh satu gaya atau daerah tertentu, namun fenomena kualitas personal secara esensi terdapat kesamaan atau kemiripan dalam daerah-daerah yang berbeda. Terdapat suatu elemen yang sifatnya konstan dimiliki oleh seniman keroncong meskipun dengan latar belakang perbedaan gaya musik keroncong, dan juga setiap daerah mempunyai kultur lokal yang berbeda namun musik yang diekspresikan pada intinya dilatarbelakangi oleh kualitas personal. Penulis dalam hal kasus ini mencoba menjadi partisipan observer juga, dengan maksud dapat ikut memahami bagaimana pola pikir dan kesadaran yang dimiliki oleh setiap personal ketika akan membawakan musik keroncong.

Kualitas Personal dalam Musik Keroncong

Musik keroncong mempunyai suatu karakteristik tertentu dalam menilai kualitas musikalnya. "Ngroncongi" merupakan istilah yang muncul dari perspektif seniman keroncong ketika melihat kualitas musik keroncong, baik yang dalam bentuk pertunjukkan maupun rekaman lagu-lagu keroncong. Beberapa gejala musikal yang muncul dalam membentuk karakteristik kualitas musik yang "ngroncongi" diantaranya rempek; lelewa; nggali; nyendaren; mbanyumili, nyacah, imbal, langsam, summonspell; nggandul, isen-isen. Gejala musikal yang membentuk kualitas musikal yang "ngroncongi" itu lebih sering diungkapkan oleh seniman keroncong yang eksis melestarikan musik keroncong di Surakarta. Penulis dalam hal ini tidak hanya membatasi ruang lingkup penelitian di kota Surakarta saja, namun peneliti juga akan melakukan penelitian ke daerah Tugu, Jakarta yang konon juga menjadi wilayah persebaran keroncong. Alasan menggunakan ruang lingkup Surakarta dan Tugu karena meskipun istilah "ngroncongi" lahir dari seniman keroncong Surakarta, namun esensi karakter kualitas musik keroncong yang memenuhi rasa "ngroncongi" diduga tidak hanya terdapat pada keroncong yang berkembang di Surakarta saja, melainkan komposisi musik keroncong dengan gaya Tugu juga memenuhi rasa yang "ngroncongi". Karakteristik kualitas musikal yang "ngroncongi" juga terbentuk dari beberapa elemen yang bersinergi untuk mencapai kualitas musikal yang "ngroncongi". Berikut merupakan alur berpikir untuk mencapai karakteristik kualitas personal yang "ngroncongi". 


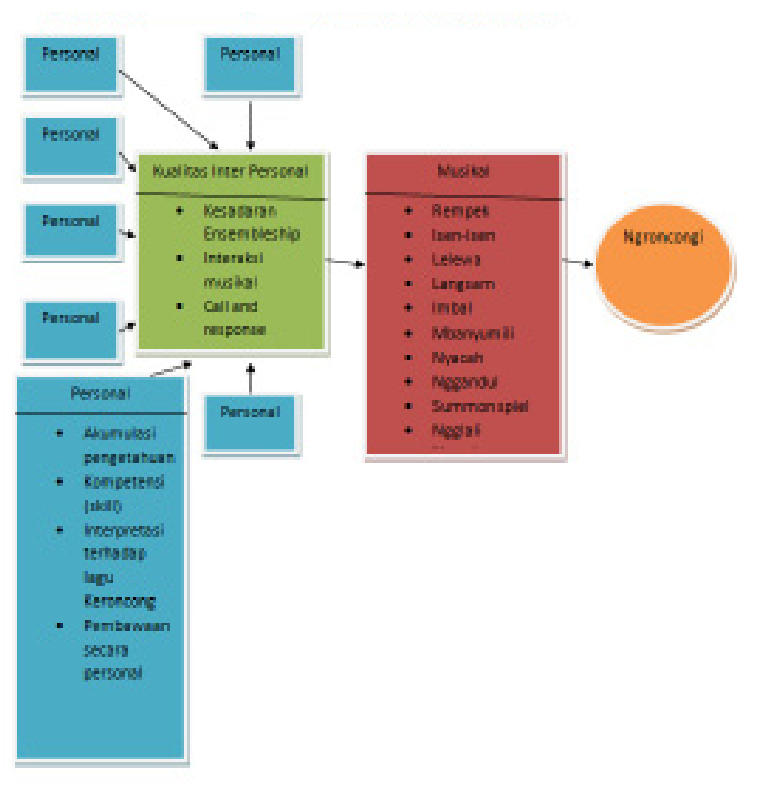

Merujuk alur berpikir untuk dapat menuju karakteristik kualitas musikal yang "ngroncongi", maka salah satu aspek yang perlu dibedah dahulu adalah kualitas personal yang dimiliki oleh diri setiap seniman keroncong. Kualitas dalam konteks tulisan ini menjadi penting untuk diungkap karena sebagai prinsip-prinsip dasar yang harus dimiliki oleh seniman keroncong untuk memainkan musik keroncong. Musik keroncong dapat menjadi harmonis apabila kualitas dari tiap personal tersebut dapat saling bersinergi agar selanjutnya dapat mancapai kualitas interpersonal. Beberapa elemen yang membentuk kualitas personal diantaranya, akumulasi pengetahuan; kompetensi (skill); interpretasi terhadap lagu keroncong; dan pembawaan secara personal.

\section{B.1. Akumulasi Pengetahuan}

Akumulasi pengetahuan yang dimiliki oleh seniman bukan bersifat pengetahuan yang bersumber pada buku, maupun literatur yang ada, melainkan pengetahuan yang bersumber dari pengalaman empiris seorang seniman keroncong. Pengalaman empiris yang dimiliki oleh seniman keroncong terkait dengan intensitas jam terbang seniman keroncong tersebut memainkan musik keroncong. Seniman keroncong memahami musik keroncong bukan berdasarkan teori yang telah dikomprehensifkan untuk selanjutnya dimainkan sesuai dengan notasi, melainkan lebih cenderung seberapa sering seniman keroncong tersebut memainkan musik ker- oncong dan seberapa sering melakukan proses dengan seniman lain yang dirasa memiliki kecocokan. Seniman keroncong tersebut terkadang bermain dengan pemain yang berlatar belakang kelompok musik yang sama, atau bermain keroncong dengan kelompok atau komunitas keroncong lain. Hal ini sifatnya temporary, apabila suatu personal bermain dengan pemain dalam ruang lingkup kelompok yang sama, maka akan mudah untuk melakukan penyesuaian dengan antar personal, baik dari segi musikal maupun psikis. Berbeda halnya apabila seorang seniman keroncong tersebut bermain musik keroncong, meskipun dengan repertoar ${ }^{1}$ yang sama, namun bermain dengan pemain yang berasal dari kelompok atau komunitas lainnya, maka dibutuhkan adanya proses adaptasi kembali. Seniman keroncong mempunyai pandangan bahwa musik keroncong, merupakan musik yang sifatnya subyektif, dan non mutlak. Berbeda halnya dengan musik klasik ${ }^{2}$ yang mempunyai ketentuan-ketentuan yang telah disepakati secara konvensional. Ketika komposisi karya musik klasik dituliskan dalam bentuk notasi, ketika dimainkan antar satu kelompok dengan kelompok lainnya, maka bunyi yang akan dihasilkan cenderung sama, karena telah dilengkapi dengan tanda seperti, dinamika ${ }^{3}$, tempo ${ }^{4}$, birama ${ }^{5}$, dan simbol-simbol yang telah dipahami dan disepakati oleh seluruh pemain musik klasik.

Seorang seniman keroncong secara individual akan memiliki pengetahuan, dan kesadaran bahwa musik keroncong dibentuk atas kompleksitas yang dibangun oleh inter personal. Seniman keroncong akan memiliki pemahaman bahwa memainkan musik keroncong bukan dalam rangka menonjolkan virtuositas $^{6}$ dari suatu individu saja, melainkan porsi seorang seniman keroncong menunjukkan virtuositasnya sangat tipis karena adanya kesadaran ensembleship dalam musik keroncong. Seorang seniman dapat mencapai kualitas personal apabila mempunyai kemampuan teknis yang cukup, disertai dengan perbendaharaan lagu keroncong yang cukup, dilengkapi dengan seringnya berproses dengan banyak seniman keroncong lainnya. Orang tersebut akan lebih siap untuk berinteraksi secara musikal dengan pemain yang latar belakangnya berbeda-beda. Kebiasaan seperti ini juga akan membawa seorang seniman keroncong mempunyai kematangan untuk mencapai tataran estetika yang dibutuhkan dalam memainkan musik keroncong.

Akumulasi pengetahuan yang dimiliki oleh seniman keroncong tersebut juga dalam rangka 
mempersiapkan apa yang akan dimainkan dalam bentuk ansambel keroncong. Pengetahuan musikal meliputi wilayah tangga nada, susunan harmoni, bentuk dan jenis-jenis keroncong sudah harus dimiliki oleh pemain keroncong sebelum akhirnya terjadi relasi interpersonal. Adanya hubungan interpersonal tersebut dapat tercapai apabila setiap individu mempunyai bekal yang matang, tidak hanya kompetensi teknis, namun pengetahuan yang cukup mengenai keroncong. Minimal apabila tidak memiliki pemahaman secara musikologis tentang apa yang dimainkan, seorang seniman tersebut paham bagaimana pola pikir dalam menyikapi musik keroncong.

\section{B.2. Kompetensi (Skill)}

Kompetensi secara teknis yang dimiliki oleh seniman keroncong diimbangi dengan seberapa banyak referensi bunyi yang didengarkan, dan pengalaman memainkan keroncong. Untuk mendapatkan beragam referensi dalam menyikapi musik keroncong, umumnya seniman keroncong mendengarkan beragam gaya musik keroncong yang ada, dan juga mempelajari permainan dari seniman-seniman keroncong yang pernah bermain dengan individu tersebut. Umumnya para seniman keroncong tidak berbekal wawasan musikologis atau bahkan teoritis yang mendalam mengenai musik keroncong, kecuali untuk keperluan aranse$m e n^{7}$. Beberapa cara tersebut akan membuat telinga mereka terlatih, didukung dengan intensitas memainkan musik keroncong untuk membantu seorang individu dalam pemantapan kompetensi secara teknis.

Realitas yang ada dilapangan, para seniman keroncong tersebut memang tidak secara general memahami notasi barat. Ada dua metode yang digunakan seniman keroncong dalam mempelajari suatu lagu yang akan dimainkan, dapat dibantu dengan dituliskannya notasi angka, maupun mengoptimalkan kepekaan telinga. Pemain depan seperti, violin dan flute diwajibkan untuk bisa membaca notasi angka, sedangkan pemain belakang seperti gitar, bass, cak, cuk, dan cello ada yang dapat memahami notasi angka, ada pula yang mengoptimalkan kepekaan telinga. Notasi angka tersebut digunakan untuk mempelajari lagu, lalu pembawaannya sesuai dengan interpretasi masing-masing personal.

Proses kreatif menjadi salah satu media untuk pendalaman kompetensi kaitannya dengan teknis yang dimiliki oleh seniman keroncong. Akumulasi pengetahuan yang kompleks mengenai keroncong, jika tidak diaplikasikan dengan media instrument juga akan membuat seniman tersebut tidak mendapat korelasi antara pengetahuan dan juga teknis, dan bagaimana mengolah rasa musikalnya.

Beberapa instrumen dalam ansambel keroncong mempunyai kerangka teknis yang berbedabeda. Jalinan antar instrumen dapat berupa jalinan pola ritme ${ }^{8}$, maupun jalinan melodi ${ }^{9}$. Salah satu ciri khas musik keroncong adalah adanya call and respon. Call and respon dalam musik keroncong dapat berfungsi sebagai kalimat tanya, dan kalimat jawab, menegaskan suatu frase, dan juga melakukan imitasi pola ritme maupun melodi. Call and respon dapat dijumpai dalam instrumentasi musik keroncong, sebagai contoh cak-cuk; violin-flute sama-sama melakukan call and respon, namun dalam kerangka teknis yang berbeda. Call and respon yang dilakukan instrument cak-cuk berupa jalinan pola ritme dan melodi yang telah terpola, sedangkan call and respon yang dilakukan instrument violin dan flute sifatnya spontan dan mengedepankan improvisasi ${ }^{10}$ dari pemainnya. Realitas yang sering dijumpai adalah seorang pemain flute ketika sedang melakukan improvisasi, pemain violin telah merekam dalam memori bagaimana wujud improvisasi instrumen flute, lalu instrument violin akan membuat melodi dan ritme yang berbeda. Salah satu strategi agar impovisasinya tidak sama, namun tetap menjadi suatu jalinan imrpovisasi adalah dengan mengambil ide ritme atau melodi satu birama terakhir yang dilakukan oleh instrument yang sebelumnya melakukan improvisasi, tetapi metode improvisasi seperti ini sifatnya tidak baku, sesuai dengan representasi gagasan setiap personal.

Ada ketentuan memperlakukan improvisasi yang dilakukan oleh instrumen flute dan violin dalam musik keroncong, yakni instrument tersebut tidak diperbolehkan terlalu panjang melakukan improvisasi hingga terjadi benturan dengan garis vokal. Terdapat bagian vokal yang hanya dapat diberikan filler ${ }^{11}$ oleh instrumen flute atau violin, dengan tujuan untuk menegaskan frase dan juga memberikan ornamentasi. Ketika vokal sedang menyanyi, kedua instrument tersebut diperbolehkan memberikan filler bersamaan pada garis vokal, tetapi hanya dalam durasi setengah, atau satu birama saja. Sebagai contoh pada keroncong asli, filler hanya dilakukan pada saat akord dominant ${ }^{12}(\mathrm{~V})$, atau pada akord supertonika ${ }^{13}$ (II), lalu kembali 
lagi ke akord dominant $(\mathrm{V})$. Filler tersebut diperbolehkan dengan pertimbangan tidak mengganggu garis vokal. Prinsipnya apabila pemain depan tidak mendengarkan bagaimana melodi vokalnya, maka improvisasi atau filler nya akan keluar dari pesan lagu tersebut.

Pembagian instrumentasi antara instrument flute dan violin tidak terdapat ketentuan yang ketat, sifatnya fleksible. Apabila bagian voorspell ${ }^{14}$ dimainkan oleh instrument flute, selanjutnya bagian introduction ${ }^{15}$ dimainkan oleh instrument violin, begitu pula sebailknya. Pada bagian bait pembagian ruang untuk memberikan filler atau improvisasi secara spontan dan bergantian saling merespon, asalkan mengerti kedudukannya. Ketika terdapat bagian vokal yang memperlihatkan keindahan liukan cengkok bernyanyinya, ada kesadaran dari kedua instrument tersebut untuk memberikan ruang pada vokal, dengan tujan membuat lagu menjadi indah. Kesadaran untuk saling mengerti secara interpersonal dalam hal ini menjadi penting dalam memainkan musik keroncong.

\section{B.3. Interpretasi Terhadap Lagu Keroncong}

Interpretasi terhadap lagu banyak dilakukan oleh para seniman keroncong, baik yang dapat membaca notasi angka maupun yang mengoptimalkan kepekaan telinga mereka. Notasi angka yang mereka baca hanya untuk mengetahui bagaimana gambaran secara garis besar lagu yang akan dimainkan. Notasi tersebut dipelajari bukan saat berada di atas panggung, melainkan diluar aktivitas pentas. Pada saat melakukan eksekusi, para pemain keroncong mempunyai kebiasaan untuk melakukan interpretasi terhadap lagu yang sedang mereka mainkan, dan hal tersebut secara spontan. Salah satu contoh yang dilakukan seniman keroncong ketika menginterpretasi suatu lagu adalah melihat struktur ritmenya. Apabila lagu tersebut memiliki struktur ritme yang relatif renggang, maka instrumen cakcuk, dan cello tidak memainkan jalinan pola ritme yang rapat dan padat. Tingkat kompleksitas permainan antar instrumen disesuaikan juga dengan konteks lagu yang akan dibawakan.

Beberapa seniman keroncong dapat melakukan interpretasi terhadap lagu tersebut berkaitan dengan peristiwa yang sifatnya non literal. Tidak semua seniman keroncong memiliki argumen musikal mengenai apa yang mereka mainkan, namun akumulasi pemahaman yang terkonstruksi mengenai musik keroncong, banyak dilatarbelakangi dari musik keroncong yang telah ada di era sebelumnya. Berdasarkan kasus penginterpretasian terhadap lagu yang dilakukan seniman keroncong, Erie Setiawan (2016:58) meruntut peristiwa yang dialami oleh seniman ketika membuat musik, Bunyi sebagai dasar musik bisa benar-benar berbunyi karena lahir atas dasar kehendak manusia. Hal itu tidak bisa dipungkiri. Sesudah berkehendak manusia berimajinasi. Dan daripadanya lahir yang kita sebut "Fakta Bunyi". Fakta bunyi dalam hal ini menjadi penting bagi seniman keroncong sebagai material untuk didengarkan, dipahami, dipelajari, dan diinterpretasi. Seniman keroncong juga mengalami proses refleksi bunyi, yang didasarkan pada bunyibunyian yang pernah didengarkan pada masa lampau, atau bahkan bunyi-bunyian yang sering kali didengar, dan secara sadar diaplikasikan ke dalam musik keroncong. Realitas yang ada pada seniman keroncong di Surakarta adalah adanya transformasi pola pikir dalam budaya musik karawitan untuk selanjutnya diaplikasikan ke dalam musik keroncong. Transformasi tersebut bisa berupa harmoni, aksentuasi, jalinan pola ritme antar instrument. Peminjaman idiom dalam musik karawitan tersebut tidak sama persis diaplikasikan ke dalam komposisi musik keroncong, namun hanya mengambil pola pikirnya saja.

Interpretasi seorang seniman keroncong saat memainkan lagu juga menyesuaikan moment saat itu. Salah satu lagu keroncong, misalnya "Rangkaian Melati", ketika dimainkan pada masa sekarang, dan apabila repertoar lagu yang sama diulang kembali realitasnya akan berbeda ide dan juga interpretasi yang dilakukan oleh seniman. Fakta bunyi yang dihasilkan pun pasti akan berbeda, baik dari aspek penghayatan, dan secara musikal. Memori masa lampau bisa saja digunakan kembali pada masa sekarang, bisa juga justru menggunakan ide baru tergantung pada bagaimana moment yang sedang dialami sekarang. Selalu muncul ide dan interpretasi yang baru bersamaan dengan panggung yang berbeda. Hal tersebut justru membuat seniman keroncong lebih dinamis dan alamiah ketika memainkan lagu, tidak adanya ketentuan secara baku saat memainkan musik keroncong.

Intuisi musikal juga mempengaruhi bagaimana ekspresi yang akan dibawakan oleh seniman keroncong. Kepekaan terhadap pemanggilan memori atau referensi musikal yang dimiliki dan pernah dilakukan pada masa lampau, akan dikaitkan 
sesuai dengan peristiwa yang sedang dialami oleh seniman keroncong tersebut. Intuisi juga bukan semata-mata datang begitu saja, namun sebagai hasil dari endapan memori (sadar) yang telah sekian lama dipunyai setiap manusia (Setiawan, 2015:16) ${ }^{16}$. Begitu mendapat rangsangan atau pesan tertentu, lalu dikombinasikan dengan pengalaman musikal, secara intuitif memunculkan sesuatu. Ada dua pandangan bahwa kasus seperti itu secara irasional, seniman mendapatkan ilham dari Sang Pencipta. Dikatakan mendapatkan ilham apabila dilihat dari latar belakang personal tersebut tidak ada yang berasal dari keluarga musik, jarang mendengarkan referensi terkait musik tersebut, dan juga tidak mempunyai pengalaman terhadap bidang tersebut. Sedangkan pemikiran rasional menganggap itu bukan mendapatkan ilham melainkan ada hubungannya dengan proses refleksi bunyi yang dialami oleh seniman keroncong berkaitan dengan pengalaman musikal pada masa lampau.

\section{B.4. Pembawaan Secara Personal}

Pada aspek pembawaan, setiap personal mempunyai kesadaran tertentu atas lagu yang akan dimainkan. Setiap pemain dalam suatu kelompok ketika membawakan suatu lagu harus memahami bagaimana konteks lagu yang akan dibawakan. Apa pesan yang terkandung di dalam lagu tersebut, bagaimana irama yang digunakan untuk melatari lagu tersebut. Hal ini nantinya berpengaruh pada aspek penghayatan. Menurut Erie Setiawan (2016:59), Bunyi kemudian berjalan menuju kesan, lalu ke persepsi, kemudian ke tafsir, dan pada puncaknya akan menghasilkan makna Tidak semua lagu keroncong menampilkan keindahan harmonisasi dengan gaya bernyanyi yang mendayu dan meliuk-meliuk, melainkan perlu adanya korelasi antara satu personal dengan personal lainnya. Sehingga yang awalnya pembawaan tersebut diawali dari personal, ketika telah dimainkan bersama menjadi pembawaan interpersonal. Adanya kesadaran antar anggota dalam ansambel musik keroncong juga penting untuk diperhatikan. Pembawaan dalam musik keroncong tidak dalam rangka untuk menunjukkan virtuositas salah satu pemain, namun harmonisasi musik keroncong tersebut dibangun secara komunal. Akan menjadi masalah apabila ada satu instrumen yang hilang dalam satu ansambel musik keroncong, karena musik keroncong mempunyai tekstur musik yang bersifat polifoni.${ }^{17}$ Setiap personal juga memiliki kesadaran membawakan lagu tersebut senikmat musik, baik nikmat dalam memainkannya juga ada pertimbangan nikmat untuk diterima oleh telinga penonton.

Pembawaan seorang seniman keroncong yang terbiasa bermain dengan gaya Surakarta, ketika akhirnya bermain bersama dengan seniman keroncong yang ada di Jogja, maupun di Tugu maka akan terjadi gesekan juga. Perlu adanya pemahaman dalam menyikapi musik keroncong. Banyaknya gaya musik keroncong yang ada di Indonesia, maka tidak dapat digeneralisasikan cara untuk membawakannya. Perlu adanya pertimbangan kepantasan budaya dari penduduk setempat terkait dimana musik keroncong tersebut dimainkan. Pembawaan secara personal dalam memainkan musik keroncong juga dipengaruhi oleh beberapa hal, diantaranya seniman tersebut berguru kepada siapa, bagaimana lingkungan dari kelompok tersebut, musik keroncong seperti apa yang sering digunakan sebagai referensi dalam bermusik. Beberapa aspek tersebut nantinya akan berpengaruh pada cara pembawaan seorang seniman ketika akan menyikapi dan menyajikan musik keroncong.

Para seniman keroncong memiliki pertimbangan orkestrasi ketika membawakan musik keroncong. Dimana hubungan dan peran antar instrumen menjadi penting. Hubungan Cello dengan bass seperti apa, hubungan cak-cuk, cello seperti apa, hubungan flute, biola, dan vokal seperti apa. Sebagai contoh ketika seniman keroncong memandang instrument bass, apakah perannya hanya memainkan nada dasar saja, atau bahkan bisa juga berfungsi untuk menuntuk instrument lain untuk patuh pada tempo dari komposisi musiknya. Bagaimana dampak secara musikal apabila instrument bass itu dihilangkan, semua telah dipikirkan sesuai dengan pertimbangan orkestrasi. Musik keroncong ketika dihubungkan dengan musik klasik mempunyai kesamaan dalam beberapa aspek, seperti sekuen atau pengulangan pola ritme, phrasering atau pengkalimatan suatu melodi, namun keroncong mempunyai dialek yang berbeda dengan musik klasik, dapat dilihat dari bagaimana cengkok yang digunakan dalam membawakan musik keroncong.

Kekuatan pembawaan dalam suatu kelompok musik keroncong nampak ketika terjadi adanya komunikasi interpersonal yang sifatnya tunggal. Maka setiap personal harus memiliki kesadaran untuk menata ego ketika memainkan instrument. Apabila setiap personal tidak dapat mengendalikan 
egonya ketika memainkan musik keroncong, yang terjadi adalah timbulnya persaingan antar personal, meskipun masih dalam bingkai musikal. Hal ini sangat dihindari oleh setiap personal seniman keroncong, karena keroncong mencapai kualitas estetisnya apabila relasi antar personal, baik psikis maupun musikal terwujud secara harmonis.

\section{Simpulan}

Kualitas personal dalam musik keroncong terbentuk oleh beberapa aspek yang saling bersinergi, diantaranya akumulasi pengetahuan; kompetensi (skill); interpretasi terhadap lagu keroncong; dan pembawaan secara personal. Akumulasi pengetahuan yang dimiliki oleh seniman keroncong pada umumnya bukan pengetahuan secara musikologis dan teoritis, pengalaman empiris menjadi media untuk memahami bagaimana pola pikir dalam bermain musik keroncong, dan wawasan yang dimiliki oleh seniman keroncong bersifat non literal. Kompetensi secara teknis yang dimiliki oleh seniman keroncong sebagai pengaplikasian atas akumulasi pengetahuan tersebut. Setiap seniman keroncong mempunyai kesadaran ensembleship, bahwa harmonisasi musik keroncong dibentuk atas dasar relasi interpersonal. Maka kompetensi yang dimiliki oleh seniman keroncong bukan dalam rangka menunjukkan virtuositas secara personal. Interpretasi terhadap lagu keroncong dilakukan oleh seniman keroncong, karena tidak semua mempunyai wawasan musikologis, dan dapat membaca notasi barat. Para seniman keroncong tersebut dapat memahami lagu yang akan mereka mainkan dengan membaca notasi angka, dan untuk yang tidak memahami notasi tersebut dapat mengoptimalkan kepekaan telinga mereka. Interpretasi terhadap lagu tersebut sifatnya alamiah, dipengaruhi oleh refleksi bunyi masa lampau dan juga peristiwa. Maka dalam satu repertoar yang sama, ketika diulang akan berbeda fakta bunyinya. Pembawaan secara personal dalam musik keroncong didasari dengan adanya kesadaran untuk memahami konteks lagu yang akan disajikan. Harmonisasi yang dibangun berhubungan dengan interaksi musikal antar personal seniman keroncong dilakukan untuk mencapai kualitas estetis dalam musik keroncong.

\section{Catatan Akhir}

${ }^{1}$ Repertoir adalah perbendaharaan lagu-lagu yang dimiliki oleh seorang penyanyi atau pemain musik yang siap diperdengarkan (Karl Edmund Prier, 2014:182).

${ }^{2}$ Musik klasik adalah musik masa lampau yang selalu memperhatikan tata tertib penyajiannya; musik serius dengan standar karya klasik walaupun diciptakan pada masa sekarang (Pono Banoe, 2003:289).

${ }^{3}$ Dinamika adalah istilah untuk membedakan keras-lembutnya dalam pembawaab karya musik (Karl-edmund prier, 2014:33).

${ }^{4}$ Tempo musik berkaitan erat dengan panjangnya hitungan dasar dalam musik dan biasanya terkait dengan dengan not $1 / 4$ dan dengan not $1 / 2$ dalam musik alla breve (Karl Edmund Prier, 2014:214).

${ }^{5}$ Birama adalah Ruas-ruas yang membagi kalimat lagu ke dalam ukuran-ukuran yang sama, ditandai dengan lambing hitungan atau bilangan tertentu (Pono Banoe, 2003:55).

${ }^{6}$ Sebenarnya istilah virtuos pada abad ke 16-17 dipakai di Italia untuk semua orang yang menonjol dalam pengetahuan, ketrampilan atau cara hidup. Namun waktu pada abad ke 18 istilah tersebut diimport ke Jerman, maka artinya dikhususkan untuk pemusik dengan ketrampilan yang istimewa. (Karl Edmund Prier, 2014: 228).

${ }^{7}$ Aransemen adalah susunan; pengolahan. Istilah ini semula muncul dalam musik hiburan untuk menyesuaikan orkestrasi dari sebuah karya musik untuk ansambel lain. Namun sekarang istilah aransemen dipakai seacara lebih luas yakni untuk segala pengolahan musik termasuk vokal yang berbeda dengan komposisi asli (Karl Edmund prier, 2014:11). ${ }^{8}$ Ritme adalah derap, langkah teratur (Pono Banoe, 2003:358).

${ }^{9}$ Melodi adalah suatu urutan nada yang utuh dan membawa makna. Adapun syaratnya adalah: berciri khas, berbentuk jelas, memuat suatu ungkapan dan dapat dinyanyikan, (Karl Edmund prier, 2014:113). ${ }^{10}$ Improvisasi adalah mencipta sesuatu tanpa persiapan sebelumnya, sifatnya spontanitas. Mengimprovisasi ini dapat terjadi atas ilham sendiri dapat juga atas dasar tema yang diberikan, (Karl Edmund prier, 2014:69).

${ }^{11}$ Fill-in adalah mengisi;isian; pasasi lagu yang dikosongkan untuk diisi secara bebas atau yang menuntut ketrampilan main salah seorang anggota pemain sebagai suatu sisipan (Pono Banoe, 2003:145). 
${ }^{12}$ Akord dominant (sol si re) merupakan antipola untuk akord tonika (do mi sol), maka urutan akord tonika-dominan menciptakan suasana tenang kembali; pada akhir kalimat ia membuat titiknya (Karl Edmund prier, 2014:36).

${ }^{13}$ Supertonika adalah nada kedua dalam urutan tangga nada, yakni nada tepat diatas tonik, (Pono Banoe,2003:398).

${ }^{14}$ Voorspell adalah permainan solo yang bebas yang mengawali sebelum masuk tempo irama keroncong (Budiman BJ, 1979:5).

${ }^{15}$ Introduction adalah Istilah untuk bagian awalan sebuah karya musik (Karl Edmund prier, 2014: 75).

${ }^{16}$ Erie Setiawan, Serba Serbi Intuisi Musikal Dan Yang Alamiah (Jogjakarta: Art Music Today, 2015), Hal 16.

${ }^{17}$ Polifoni adalah istilah untuk musik seni dengan lebih dari satu suara yang secara ritmis dan melodis berdikari namun saling melengkapi, (karl Edmund prier, 2014:163).

\section{Kepustakaan}

Erie Setiawan. Musik Untuk Kehidupan. Yogyakarta: Art Music Today, 2016.

Budiman BJ. Mengenal Keroncong Dari Dekat. Jakarta: 1979.

Edmund Prier SJ, Karl. Kamus Musik. Yogyakarta: Pusat Musik Liturgi, 2014.

Erie Setiawan. Serba-Serbi Intuisi Musikal Dan Yang Alamiah Dari Peristiwa Musik. Yogyakarta: Art Music Today, 2015.

Banoe, Pono. Kamus Musik. Yogyakarta: Percetakan Kanisius, 2003.

Harmunah, S.Mus. Musik Keroncong Sejarah Gaya dan Perkembangan. Yogyakarta: Pusat Musik Liturgi, 1996 